DOI: 10.30842/ielcp230690152431

\author{
A. V. Lebedev \\ (RAS Institute of philosophy)
}

\title{
DEMOCRITUS ON IRANIAN MAGI AND ANCIENT RELIGION: a quotation from Avesta (Yt.1.7) in Democritus fragment 580 Luria (= B 30 DK)
}

In this paper a new reconstruction of the text and interpretation of the fragment 580 Luria / B $30 \mathrm{DK}$ is proposed. The author refutes the widespread opinion going back to Reinhardt (1912), according to which the fragment speaks of ancient sages, and argues that those who pray in the open air and call 'Zeus' air, are Iranian magi performing a Zoroastrian ritual. The fragment comes from the 'Small Diakosmos' of Democritus, which expounded the history of civilization and the origin of religion. For the reconstruction of the ancient phase of religion, Democritus uses the principle "as among barbarians now, so among the Greeks in ancient times", which was widespread in the epoch of Sophists. The worship of the elements, preserved by the Persians, the absence of temples and statues, is a relic of the ancient phase of religion, which was replaced in Greece by the worship of anthropomorphic gods, a religion of "fools".

Key words: ancient philosophy, Presocratics, Democritus, Derveni papyrus, Herodotus, atomism, Avesta, Persian magi, Zoroastrianism, origin of religion.

\section{А. В. Лебедев \\ (Институт философии РАН)}

\section{Демокрит об иранских магах и религии древних: цитата из «Авесты» (Яшт I, 7) в фр. 580 Luria (= B 30 DK)}

В работе предлагается новая реконструкция текста и интерпретация фрагмента. Опровергается восходящая к Райнхардту (1912) точка зрения, согласно которой в нем говорится о древних мудрецах, и доказывается, что молящиеся под открытым небом и называющие «Зевсом» воздух - иранские маги, совершающие зороастрийский обряд. Фрагмент происходит из «Малого мироустройства» Демокрита, в котором излагалась история цивилизации и происхождение религии. Демокрит использует для реконструкции древней фазы религии распространенный в эпоху софистики принцип «как у варваров сейчас, так у нас в старину». Сохранившееся у персов почитание стихий, отсутствие храмов и статуй, является пережитком древней фазы религии, на смену которой у греков пришла «глупая» вера в антропоморфных богов.

Ключевые слова: античная философия, ранняя греческая философия, атомистика, Демокрит, Папирус из Дервени, Геродот, зороастризм, персидские маги, Авеста, происхождение религии. 
The fragment of Democritus 580 Luria (= B $30 \mathrm{DK}$ ) is quoted twice by Clement of Alexandria, the first time in Protrepticus (henceforward "P version"), the second time in Stromata Book V (henceforward "S version").

(P) Clem. Alex., Protrept. 68 (Bd. I, 52, 16-20 St.) ö $\theta \varepsilon v$ oủк

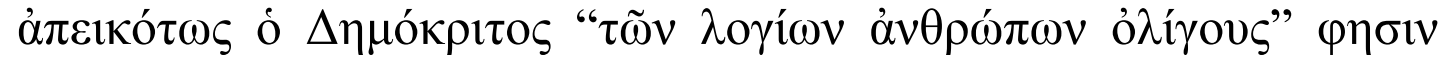

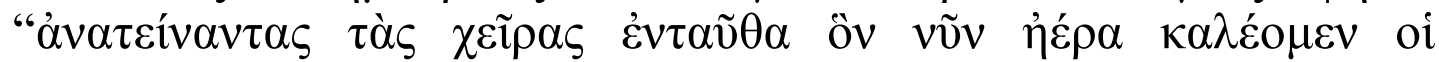

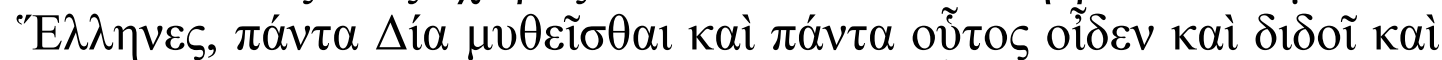

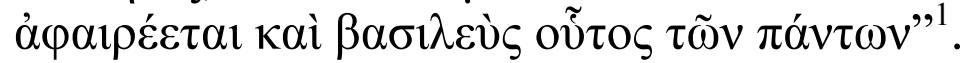

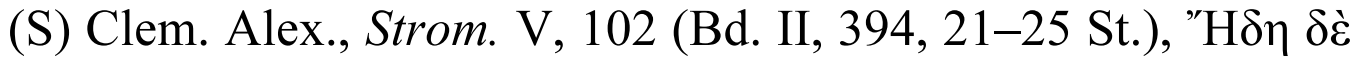

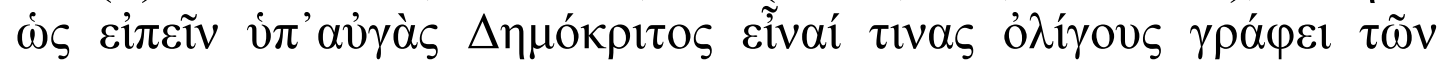

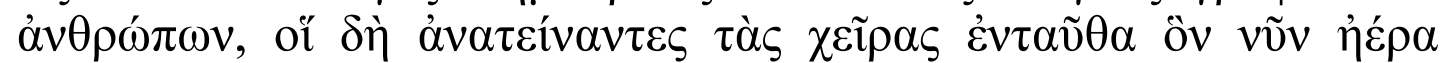

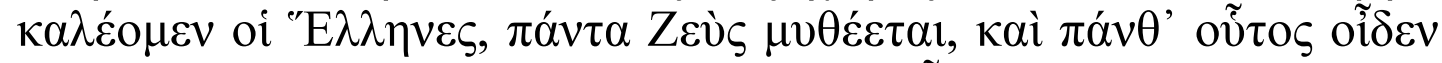

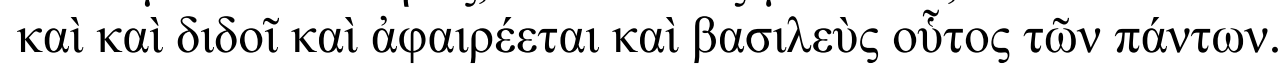

The edition of Diels-Kranz prints as fragment 68 B 30 the following reconstruction of the Greek text of Democritus with a German translation, based on these two versions, restoring the oratio recta of the original instead of the oratio obliqua of Clement's quotes that depends on $\varphi \eta \sigma i ́ v$ and $\gamma \rho \alpha ́ \varphi \varepsilon \varepsilon$ :

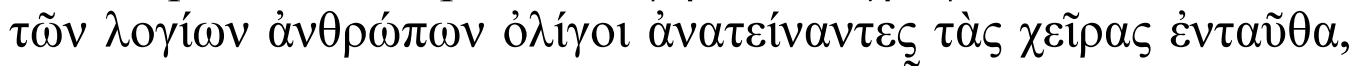

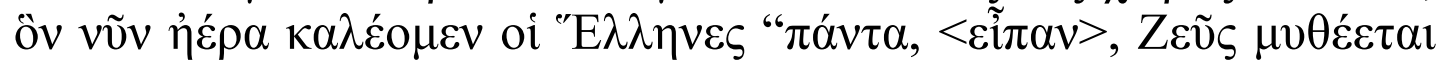

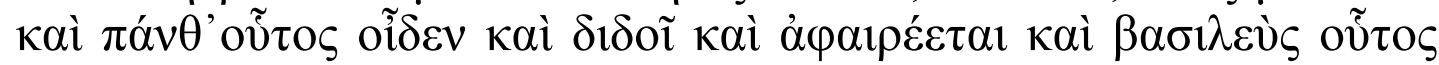
$\tau \tilde{\omega} v \pi \alpha ́ v \tau \omega v "$ " "Von den denkenden Menschen erhoben wenige ihre Hände zu dem Orte, den wir Hellenen jetzt Luft nennen, und sprachen dabei: Alles beredet Zeus mit sich (?) und alles weiss und gibt und nimmt er und König ist er über alles insgesamt".

The insertion of aorist zĩ $\pi \alpha v$ belongs to Reinhardt (1912) and was accepted by Kranz in the 5th edition of DK (1935, the 4th edition of Diels 1922 has pariv), it is based on the (incorrect) assumption that Democritus refers to the ancient sages. The unusual

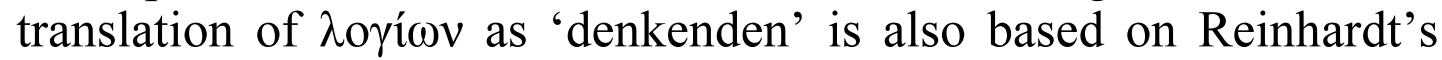
(another incorrect) assumption that these ancient sages in their new monotheistic theology allegedly rose above the ignorant crowd (this is essentially a repetition of Clement's Christian interpretation). In the edition of Luria (1970), the Greek text follows DK exactly, but the translation is different: "Some of the wiseacres stretching out their hands to this place that we, the Greeks, now call the air, said: "Zeus gives a name to everything, and he knows everything, and

\footnotetext{
${ }^{1}$ We remove from Stählin's text of Protrepticus three mistaken alterations by Wilamowitz that have been rightly rejected already by Diels in early editions and Kranz in DK.
} 
gives, and takes, and he is the king of everything." Justifiably criticizing in the commentary to fr.580 Reinhardt's thesis that Democritus allegedly considered the invention of religion by the ancient sages a high cultural achievement, Luria, however, goes to the other extreme, interpreting the text in a straightforward "atheistic" way and understanding $\lambda$ ó $\gamma 101$ as an ironic mockery of the first theologians (hence умники 'wiseacres').

The attempt by Diels and Luria ${ }^{2}$ to find irony in the word $\lambda o \gamma$ í $\omega \mathrm{v}$ is unconvincing: looking at dozens and dozens of examples of the use of this word in TLG-online, you cannot find a single instance that provides a parallel to such hypothesized meaning: $\lambda$ ó $\gamma$ ıo always has a positive connotation of respect, indicating extraordinary knowledge or high authority, and often is employed as a synonym

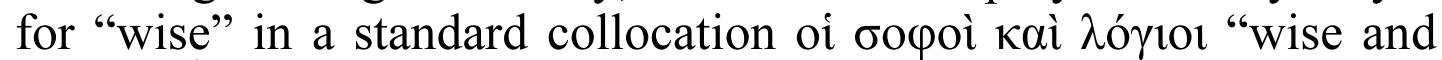

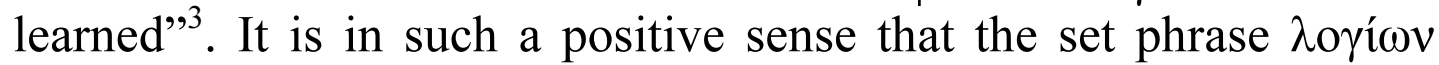
$\dot{\alpha} v \theta \rho \omega ́ \pi \omega v$ is used by Democritus himself in a genuine auto-

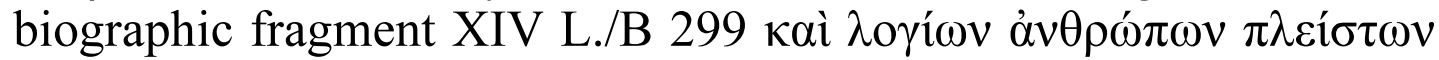
$\dot{\varepsilon} \pi \eta \kappa_{\kappa} \sigma 0 \alpha \alpha$ "and I have listened to the greatest number of learned men". The style of this fragment is typical for the Ionian scientific (in this case ethnographic) prose, the style of empirical, objective

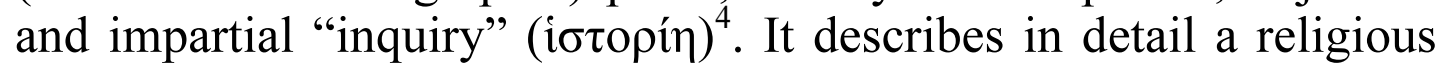
ritual, apparently regularly performed at the present time, not in the past. First comes the indication of place: the ritual is performed in the open air ( $\dot{v} \pi^{\prime} \alpha \dot{v} \gamma \alpha \grave{s} \varsigma$ ), then follows the description of the prayer pose (hands lifted up), and then a precise quotation of the words of the prayer or hymn with cult epikleseis or sacred names of the supreme god. The "learned men" here are obviously priests of a certain cult: the word $\lambda$ ó $\gamma 10$ was often applied to priests and diviners (manteis) as religious experts and carriers of traditional

\footnotetext{
${ }^{2}$ For Diels the object of irony was Diogenes of Apollonia, for Luria ancient theologians who invented religion and god.

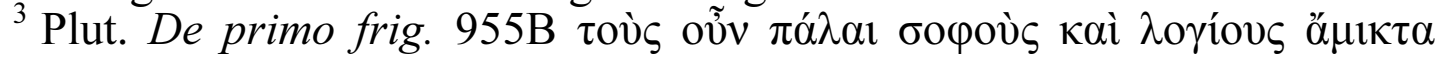

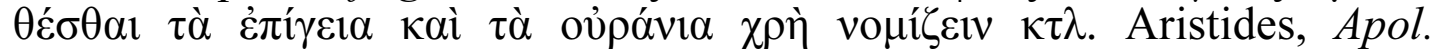

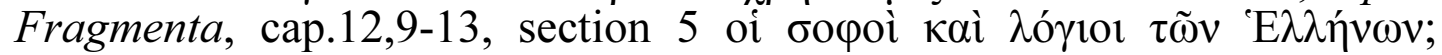

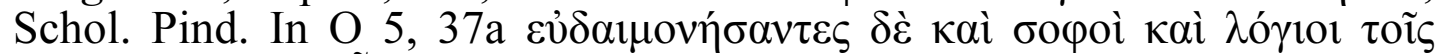

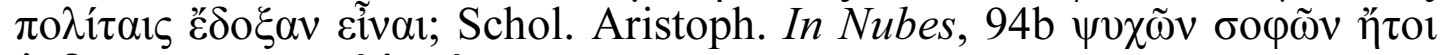

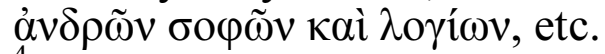

${ }^{4}$ The monograph of Aristid Dovatour "The scientific and narrative style of Herodotus" (1958) remains an exemplary study not only of language and style, but also of social functioning of texts, of readers' audience etc., i. e. approaches that are currently important, cf. e. g. Harris 2018: 79-113; Luraghi 2007, etc.
} 
knowledge 5 . The words "we, the Greeks call" imply a contrast or distinction between the designation of atmosphere in the Greek language of Democritus' time ( $v \tilde{v} v$ ), and in the language of the "learned men". Which means that the language of the leaned men is not Greek. Priests that do not speak Greek, are barbarian priests. In Greek texts that address the topic of the "wisdom" of barbarians, Egyptian priests, Persian magoi and "Chaldeans" of Babylon (Zoroaster) are mentioned primarily and most often, followed by Indian gymnosophistai, Celtic druids and others. In the early Greek tradition on Persian magi ${ }^{6}$, the peculiar and amazing to Greeks feature of their religious worship, is that they have no temples and altars, and that they pray and sacrifice in the open air. Another amazing feature of their religious faith and customs from the Greek point of view is that they have no statues and do not conceive the gods as having a human shape ( $\dot{\alpha} v \theta \rho \omega \pi$ o $\varphi v \varepsilon \dot{\varepsilon} \alpha \varsigma)$, instead they worship the elements such as fire, water and winds, and "call 'Zeus'

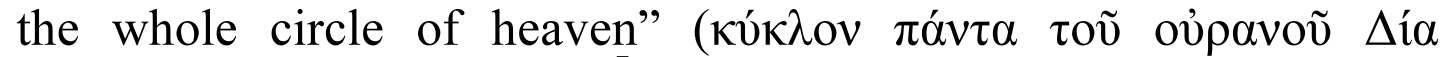
$\kappa \alpha \lambda \dot{\varepsilon}$ ov $\tau \varepsilon \varsigma$, Herodot. I, 131) ${ }^{7}$. Therefore, it seems virtually certain that the "learned men" in Democritus' fragment 580Luria/B30DK are genuine Iranian magoi performing the same Zoroastrian sacrificial ritual that Herodotus describes in detail in the first book of History (Herod. I, 131-132). But unlike the 'pious' Herodotus,

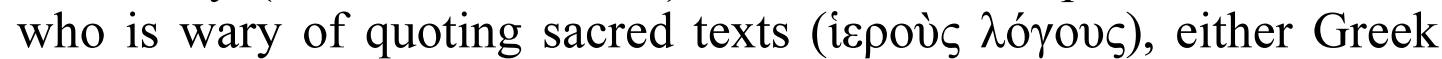
and barbarian, Democritus not only describes the dromena, but also quotes precisely the legomena. 'Zeus', implored by the "learned men", is no other than 'Implorable' Ahura Mazda ('Wise Lord'), whereas the words of glorification in their prayer find exact matches in the Avesta, namely in Yasht 1, which contains a list of "20 names" of the supreme god.

\footnotetext{
${ }^{5} \Lambda$ ó $\gamma 101$ of priests: Brahmanes: Ael. De nat. anim. 16.20; Egyptian priests: Herod.2.3; Phil Iud. De vita Mosis, 1.23; Ael. Arist., In Sarap.51.8; Tyrrhenian diviners: Plut., Sulla 7.3; Greek diviners: Dionys.Geogr., Per.Bosp.navig. 24.

${ }^{6}$ On Iranian magi and Zoroaster in early Greek philosophy see: Kingsley 1995; De Jong 1997; Vasunia 2007; Tuplin 2007; Horky 2009.

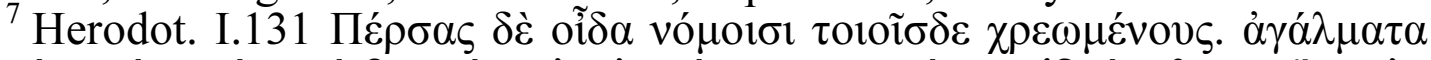

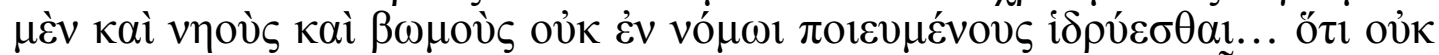
àv $\theta \rho \omega \pi$ o

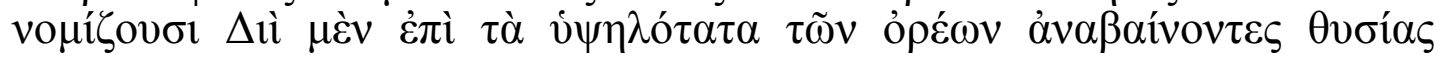

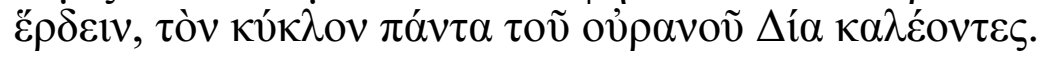


Ohrmazd Yašt, 7-8 $\quad$ Democritus fr. 580 Luria / B30 DK

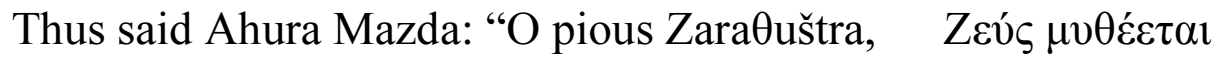

I am by name, 'He who is to be implored',

second, 'Shepherd',

third, 'Able (?)',

fourth, '(O) Best Truth',

fifth, '(O you who are) Every Good Thing Created'

by Mazda having its seed in Truth',

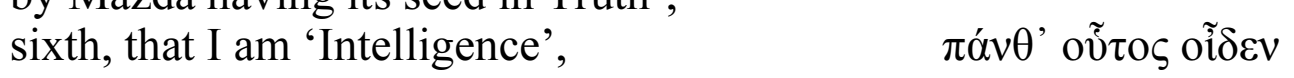

seventh, 'Intelligent',

eighth, that I am 'Insight',

ninth, 'Insightful',

tenth, that I am, 'Beneficence',

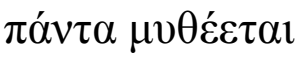

eleventh, "Beneficent',

twelth, 'Lord',

thirteenth, 'Most Powerful'

Seventeenth, 'All seeing (?)'

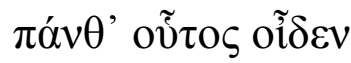

All epikleseis (invocations) of 'Zeus' in the prayer of 'learned men' have a match in the list of names of Ahura Mazda in Yasht 1 of the Avesta, and are listed in the same order. Democritus quotes Avesta in an abbreviated translation. We have no evidence on the

${ }^{8}$ The text of Yasht 1 is that of Geldner 1896 61-62 as transcribed by Panaiono 2002: 25-26. The English translation is also by Panaiono.

Avest., Yt, 1, 7

àat mraot ahurō mazdā: $\quad$ Thus said Ahura Mazda: "O pious ZaraӨustra' fraxštiia nąma ahmi ašāum zara\}uštra

bitiiō vą̧ßiiō

Yritiiō auua.tanuiiōo

tūiriia aša vahišta

puxठa vīspa vohu

Created

mazdadāta ašaci@ra

xštuuō yat ahmi xratuš

hapta $\bar{o}$ xratuma $\bar{a}^{\circ}$

aštzmō yat ahmi cistiš

nāumō cistiuu $\bar{a}^{\circ}$

Avest., Yt, 1, 8

dasamō yat ahmi spānō

aēuuandasō spanayuhā

duuadasō ahurō

Yridasō sauuištō

haptadasa vīspa.hišas
I am by name 'He who is to be implored', second, 'Shepherd', third, 'Able' (?), fourth, '(O) Best Truth', fifth, '(O you who are) Every Good Thing

by Mazda having its seed in Truth', sixth, that I am, 'Intelligence', seventh, 'Intelligent', eight, that I am, 'Insight' ninth, 'Insightful',

tenth, that I am, 'Beneficence' eleventh, 'Beneficent', twelfth, 'Lord', thirteenth, 'Most Powerful',

seventeenth All-Seeing (?)" 
existence of Greek translations of the Persian Avesta in the second half of the 5th century or the beginning of the 4th. centuries B.C. It seems, therefore, more likely that Democritus employs his own translation of the prayer that he recorded on one of his "exploration"

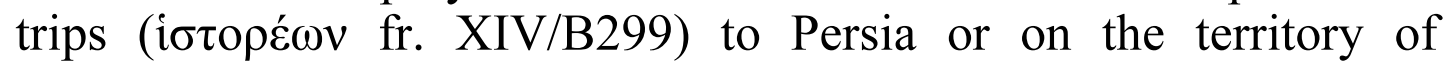
Achaemenid Asia Minor. Until now, one could assume Democritus' knowledge of ancient Egyptian and Middle Eastern languages ${ }^{9}$. The catalog of his writings contains a treatise on the Babylonian grammata; certain ancient critics of Democritus accused him of translating the sayings of Ahikar into Greek and inserting them in his own ethical writings ${ }^{10}$. Now with even greater reason we can assume that Democritus knew the ancient Persian and Avestan language.

In the genuine autobiographic fragment quoted by Clement (the authenticity of which was wrongly denied by Diels) Democritus tells the story himself.

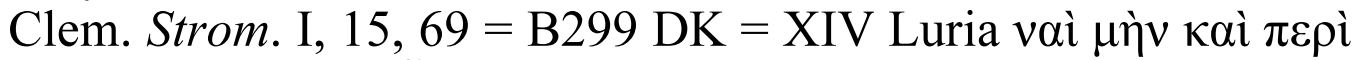

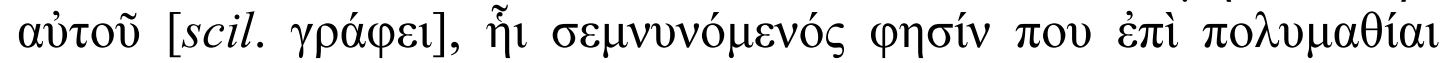

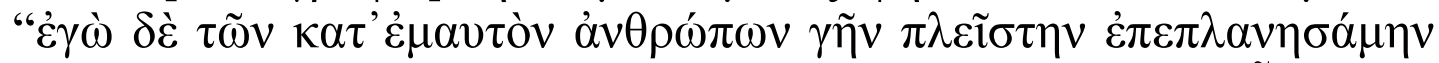

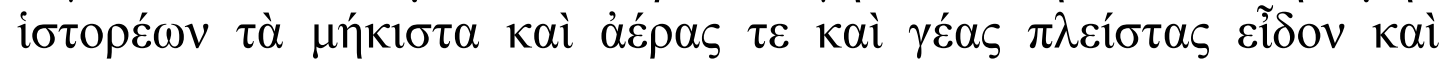

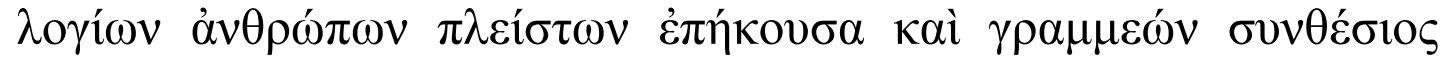

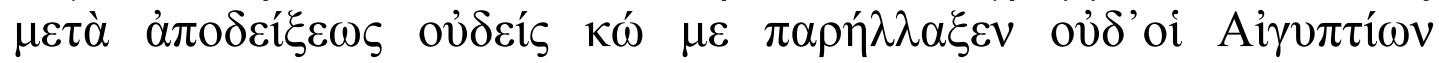

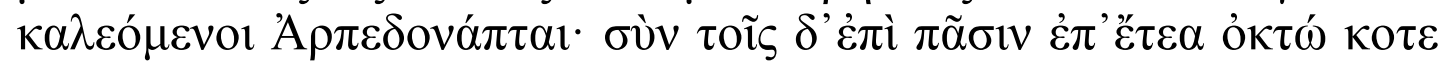

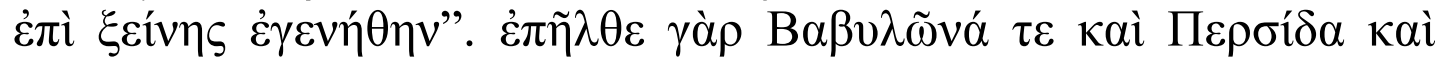

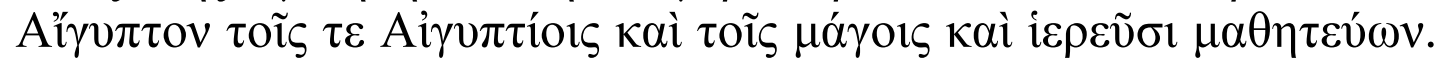
"Moreover, he writes about himself [scil. that he learnt from barbarians] in a passage in which he is boasting of his much learning: 'Of all my contemporaries I have travelled on earth more than anyone else, while conducting research in most distant places, and I have seen more climates and lands [than anyone], and I have listened [or learned] from most learned men, and no one has surpassed me in the art of the composition of lines and demonstration, nor even the Egyptian arpentators, as they are called. Together with them, all in all, I have stayed abroad for eight years or so" $" 11$.

\footnotetext{
${ }^{9}$ See biographical testimonia XIV-XXII Luria.

${ }^{10}$ D. L. $9.49=$ test. CXV L.; Clem. Alex., Strom. I.15.69 = test. XIV L.

${ }^{11}$ For a persuasive defense of authenticity of fr. B299 DK (= test. XIV Luria) with comprehensive refutation of all Diels's reasons for regarding it as spurious see Luria's commentary to test. XIV, p. 389-391 (= pp. 911916 of the Italian 2007 translation). We only disagree with the unnecessary

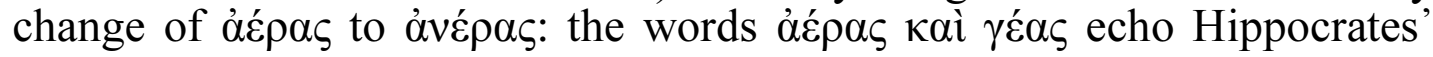


The concluding remark of Clement $(\dot{\varepsilon} \pi \tilde{\eta} \lambda \theta \varepsilon \ldots \mu \alpha \theta \eta \tau \varepsilon v ́ \omega v)$ should be taken not as reference to some other evidence or some other sources, but as an explicative commentary ( $\gamma \alpha \dot{\alpha} \rho$ !) to the fragment he just quoted. Clement quotes verbatim only the introduction to Democritus' description of his travels, and adds a summary of what Democritus narrated in detail after this proem with a list of countries Democritus mentioned himself.

The ancient biographical evidence on Democritus' connections with Iranian magi is full of unusual details and peculiar circumstances. We hear not only about his trips to Persia, but also about "family tradition" that connects him with magi straight from his childhood. Allegedly, Xerxes, while passing in the campaign of 480 B.C. the Northern Greece on his way to Athens, stayed in Abdera in the house of Democritus' father who offered him hospitality. In gratitude for this the Persian king sent him magi who became tutors of young Democritus teaching him theology and astronomy ${ }^{12}$. There is nothing incredible in the story of Xerxes staying overnight in a house of a rich citizen of Abdera, there may have been magoi in king's retinue as well. Democritus, who was fond of autobiographical notes in his philosophical works, may have mentioned this fact alone, from which a legend of magoi as tutors may have been constructed by later biographers. Such family ties of hospitality with the Persian court could provide Democritus with a

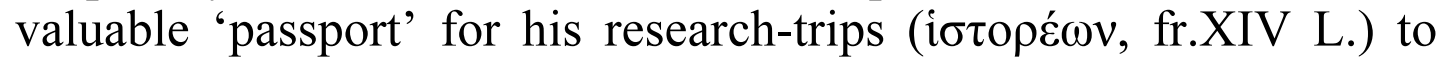
Persia and a 'recommendation' for Persian magoi, as well as a 'transit visa' for traveling to Babylon ${ }^{13}$.

Relying only on the analysis of the text and firmly established facts, we propose the following reading and interpretation of the fragment.

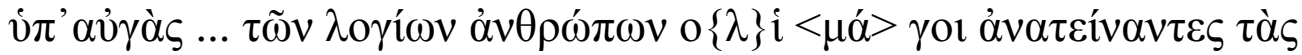

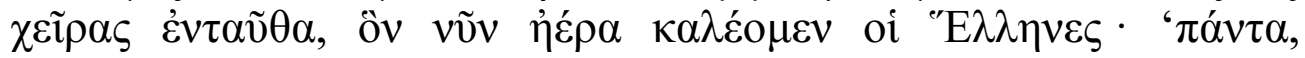

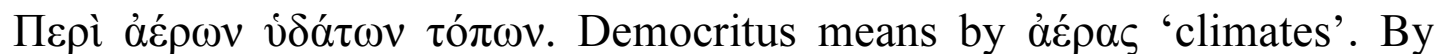
claiming that he visited climates no Greek had ever seen, he probably alludes, inter alia, to southernmost latitudes like Meroe. The omission of B299 without replying to Luria's objections to Diels in Taylor (1999) and Gemelli (2013) is a regrettable mistake. The fragment 580L./B30 as interpreted in this study provides additional proof of the authenticity of B299.

${ }_{12}$ D. L. 9.4 = Democr. Test. XI Luria.

13 Could Democritus' father and Persian king exchange 'tokens of hospitality'? Could Xerxes give his father a gift with a royal stamp or another proof that it was a royal gift? Any object of this kind, preserved as a family treasure, would open to Democritus all doors in Persia. 


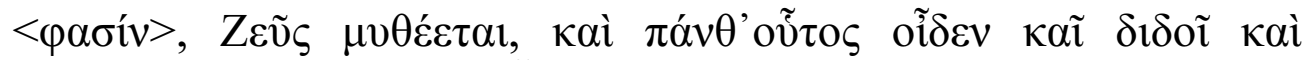

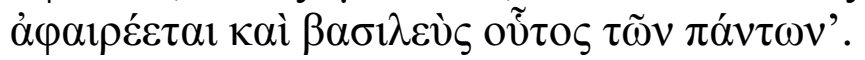

oi $\mu$ ó́

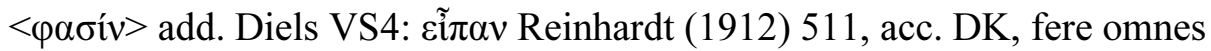

"Under the rays of the sun ... the learned men $<$ called $>$ magoi, raising their hands to what we, the Greeks, now call 'air', say: «Zeus foretells everything, and he knows everything, and he gives and takes away $<$ everything $>$, and he is the king of all $<$ beings $>$ »)."

We will first discuss the original context and propose a general interpretation of the fragment. After this we will provide a line-byline commentary to the fragment. In the early editions of $V S$ Diels incorrectly considered this text a personal polemic of Democritus with Diogenes from Apollonia (A 8 DK). After the work of Reinhardt (1912), Kranz, Luria and most of the subsequent researchers correctly connected fr. 580 L./B30 (as published in DK) with the Democritus' theory of the origin of religion ${ }^{14}$, at the same time they committed a mistake by identifying the "learned men" with ancient sages. The doxographical testimonia on Democritus' theory at issue fall into two main groups, whose relation has been a subject of controversy. According to the first, ancient humans, amazed and frightened by celestial phenomena (such lightning and thunder, eclipses, phases of the moon etc.), the causes of which they could not understand, attributed them to imaginary beings they called 'gods'. The second theory explains the origin of the anthropomorphic images of traditional Greek gods, by the atomic 'ghosts' ( $\varepsilon i \delta \omega \lambda \alpha)$, that appeared to men in their dreams and in a state of wakefulness. These theories may be contrasted as historical (anthropological) versus psychological, or as a focusing on visible "meteorological" phenomena versus focusing on extrasensory perception. Only the second, but not the first, is inextricably linked with atomism. If the fragment $580 \mathrm{~L} / \mathrm{B} 30$ derives from a context relating to the origin of religion (as we believe it does), it better fits the first, not the second theory; at least, it does not contain any explicit reference or even an allusion to the eidola or dreams. However, as we have seen above, the text itself is not a historical narrative, but an anthropological document, and it speaks of Iranian magi contemporary with Democritus, and not of "ancient sages".

\footnotetext{
${ }^{14}$ Reinhardt 1912; Diels-Kranz I, 151. adn.11; Luria 1970: 556-557; Cole 1967: 202-204; Taylor 1999: 215; Gemelli 2013: 519 ff.; Winiarczyk 2016: 69, n. 98. More skeptical is the position of Henrichs 1975: 103-104 n. 48 .
} 
The image of "ancient sages" appeared in the scholarly literature discussing the anthropological (aka meteorological) theory of Democritus for the first time in the article of Carl Reinhardt (1912), it derives from a mistaken interpretation of the phrase $\lambda$ oyí $\omega \mathrm{v}$ $\dot{\alpha} v \theta \rho \omega ́ \pi \omega v$, and the only 'supporting evidence' on which it is 'based', is the equally mistaken insertion in the text of a verb in historical tense 'they said' ( $\varepsilon \tilde{i} \pi \alpha v)$, which, in turn, is really based on the same mistaken interpretation of the phrase. The aorist form as such looks suspicious: how could Democritus (a serious scientist) claim that he knew what exactly was once 'said' by some unspecified 'learned men' in antedeluvian times? How in principle was possible the existence of "learned men" at a time when, according to Democritus, there was no civilization, no writing, no science? In the parallel from Lucretius (V, $1186 \mathrm{ff}$.), first quoted by Reinhardt and afterwards innumerable times by his followers, a more natural imperfectum is used: perfugium sibi habebant omnia divis tradere. Lucretius, following Epicurus and Democritus, treats these ignorant people with pity and contempt, he does not consider them wise at all. So where is the 'parallel'? In a similar stance, Prodicus in his theory of the origin of religion and civilization described the life of the primitive men before the invention of tekhnai and agriculture as wretched and miserable ${ }^{15}$. In the sophistic treatise on the origin of religion, known as Derveni papyrus, which we identify with the Epochs ( $(\Omega \rho \alpha)$ of Prodicus of Ceos and date to the decade 430-420 BC, the ritual of Iranian magoi (PDerv.col.VI) is presented as a piece of anthropological "evidence" $(\tau \varepsilon \kappa \mu \eta ́ p ı v))^{16}$,

${ }^{15}$ The verses of Aristophanes Aves, 685-687 (= Prodicus fr. 69 Mayhew) contain a parody of the description of miserable condition of primitive men (neglected in DK) in Prodicus' Kulturgeschichte Horai, cf. Mayhew 2011: 171; Lebedev 2019: 519.

${ }^{16}$ On the importance of the underestimated concept of empirical evidence

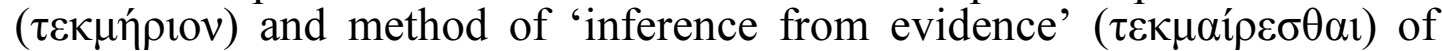
early Greek science and medicine see our commentary to the new reading of Alcmaeon fr. B1 in Lebedev 20173: 227-229. The Ionian physikoi employed this method for the reconstruction of the natural history of the cosmos. The Sophists in their history of culture and civilization (and Democritus in his Mikros Diakosmos) have borrowed this method from the Ionian science and employed it for the reconstruction of the previous stages of society, religion and language, looking for archaic 'survivals' in barbarian cultures. Aristophanes parodies Prodicus' use of $\tau \varepsilon \kappa \mu \alpha i ́ p \varepsilon \sigma \theta \alpha \mathrm{l}$ method for the reconstruction of ancient history in a comic digression on the 'Persian cock' in Aves 481-492: the upright comb of the Persian cock is a survival and tekmerion that proves that he was the first Persian king as 
as a survival or a remnant of the ancient religion (after the invention of agriculture) of the ancestors of the Greeks who at that time worshiped the elements and luminaries, rather than the fantastic anthropomorphic images of the gods invented later by the poets ${ }^{17}$. The poets (Orpheus) invented not only fantastic images, but also "peculiar" names of the gods ('i $\delta 1 \alpha$ óvó $\mu \alpha \tau \alpha$ ) some of which originally were "common names" with clear simple meaning, like

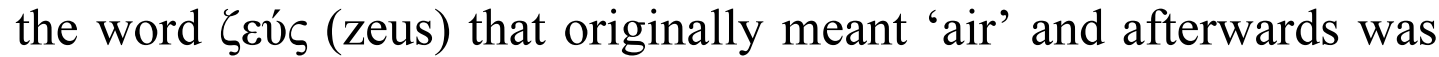
misapplied by the ignorant polloi to a fantastic image of a formidable man with a thunderbolt. The "open air" ancient worship of Persian magi proved that in ancient times temples and altars did not exist. In the sophistic history of culture and civilization, which also dealt with the origin of language and religion, for the reconstruction of the "primitive" religion was used contemporary anthropological evidence, the supposed "survivals" of ancient religious ideas and rituals among barbarians according to the

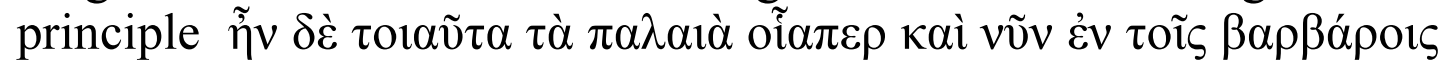
"ancients customs (scil. of the Greeks) were like those that exist now among the barbarians" 18 , since it was believed that the religion of the barbarians stayed at an earlier stage of development than the Greek and therefore retained archaic elements that have long disappeared from the Greek culture ${ }^{19}$.

This method of historical reconstruction of the ancient state of culture and religion from "remnants", common to Democritus and the Sophists, reveals a striking typological resemblance to the concept of "survivals" in 19th-century anthropology, introduced by Edward Tylor in his Primitive culture (1871). Taylor admitted himself that he owed his theory of the origin of religious beliefs

among Persians the right to wear an upright cap is a royal privilege (for details see Lebedev 2019: 577-578).

${ }^{17}$ For a detailed reconstruction of Prodicus' theory of the origin of religion and language see our study of the Derveni papyrus: Lebedev (2019).

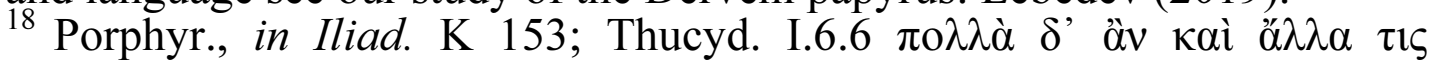

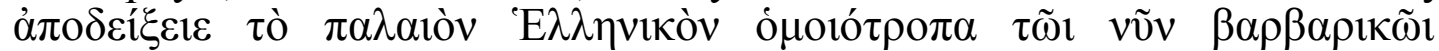

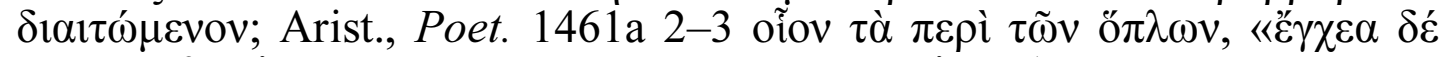

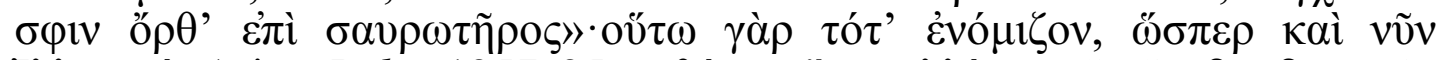

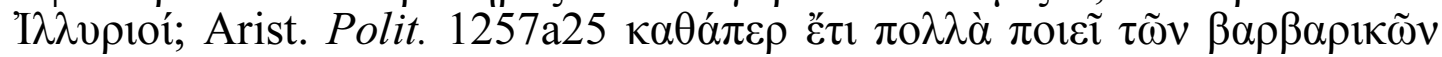

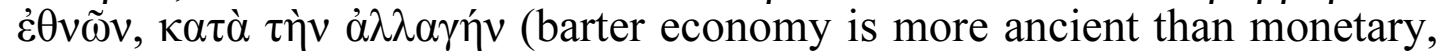

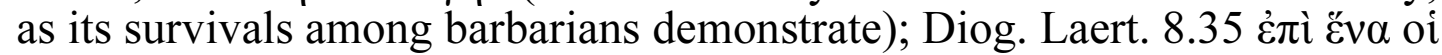

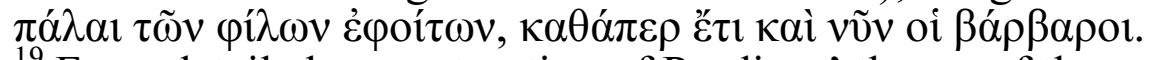

${ }^{19}$ For a detailed reconstruction of Prodicus' theory of the origin of religion and language see our study of the Derveni papyrus (Lebedev 2019). 
from dreams to Democritus ${ }^{20}$. The common theory of the origin of mythological names of gods, shared by Democritus with Prodicus and the Derveni author (= Horai of Prodicus), which explains them as a result of a "language error", reveals a striking similarity with the theory of myth as a "disease of language" advanced by Max Müller exactly at the same time. The theory of the "disease of language" in Max Müller is, in turn, inextricable linked with the nature-myth school. One may speak not just of 'similarity' between the common Sophistic-Democritean theory of mythology on the one hand, and Max Müller's, on the other, but of their identity: they look like twin brothers. In Prodicus, in the Derveni papyrus and in Democritus, names of the gods were originally simple words denoting natural phenomena whose meaning was later obfuscated due to a 'language error' or a 'disease of language' as a result of which they were reattached to fantastic images invented by poets ${ }^{21}$. We cannot date Democritus' fragment under discussion with precision, but it is worth noticing that the date of the Derveni papyrus (430-420 B.C.), established on independent grounds, comes close to the possible time of Democritus visit and stay in Athens (late thirties - early twenties). Democritus was a close associate of Protagoras, the teacher of Prodicus. The views of Democritus and Prodicus on the origin of religion are very similar. We have argued for a possible influence of Democritus' cosmogonic mechanism of 'squeezing out' ('̌ $\kappa \theta \lambda \psi \psi 1 \varsigma$ ) of corpuscles, resulting in their 'popping off' $(\theta$ ó $\rho v v \sigma \theta \alpha$ l), in the cosmogonic passages of the Derveni papyrus (Lebedev 2019: 556-557).

According to a well-argued theory, all later versions of the Greek anthropological and technological history go back to a common source, Democritus (Reinhardt 1912, Cole 1967). We would subscribe to it with some reservations. Democritus may be a very important source of this tradition, but perhaps not the earliest and not the only one. Protagoras was much older than Democritus. Democritus polemicized with Protagoras over his phenomenalism. It

${ }^{20}$ The anthropology of Democritus and Tylor is compared by Franek 2013: 66 and Roubekas 2017: 36-37.

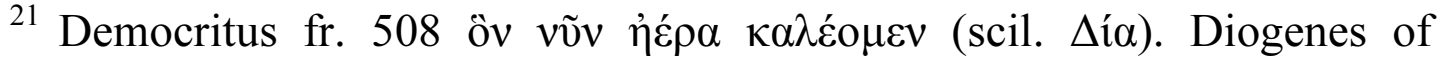
Apollonia A 8, pace Diels, depends on Democritus or the Ionian sophists like Prodicus. The myth of the birth of Dionysus in Euripides' Bacchai is

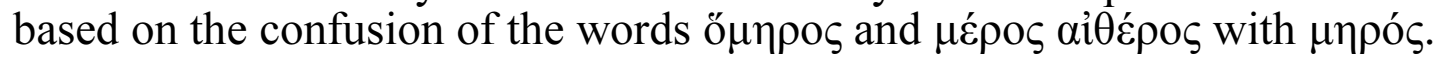
ǒvo $\mu \alpha \mu \varepsilon \tau \alpha \sigma \tau \eta ́ \sigma \alpha v \tau \varepsilon \varsigma$ (Eurip. Bacch. 296 from Prodicus) can be compared

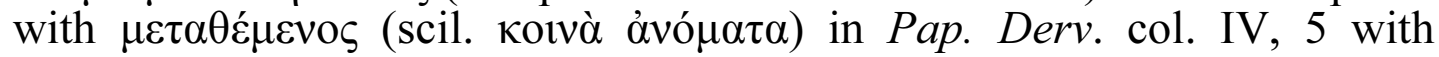
comm. in Lebedev 2019: $539 \mathrm{ff}$. 
cannot be assumed that Protagoras' treatises "On the Primeval

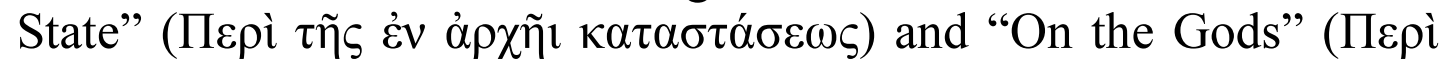
$\theta \varepsilon \tilde{\omega} v)$ were written after the Great and Small Diakosmoi of Democritus or were inspired by Democritus. The new anthropology of the Sophists and Democritus was a 'child' of the new naturalistic picture of the world, created by the 6th century B.C. scientific revolution in Miletus. The cosmogony of Anaximander ended with zoogony and the origin of man as a biological species. Archelaus in his treatise "On Nature" supplemented the Ionian cosmogony with a history of the origin of civilization and the origin of laws and the state (60 A 1, A 4). A new evolutionary history of the cosmos produced a new history of civilization based on the idea of progress. Once the gods have been eliminated from cosmology, they could not play and role in human history, either. A fragment of Xenophanes proves that the idea of progress unaided by gods goes back to the $6^{\text {th }}$ century $^{22}$. The Athenian enlightenment of the $5^{\text {th }}$ century may have been preceded by the Ionian enlightenment in the $6^{\text {th }}$. Anaxagoras and Democritus, as well as Ionian sophists like Protagoras and Prodicus, provided a bridge between the two. The clash between naturalistic evolutionism of the Ionian science and divine creationism of popular religion (creationism in wide sense, including all traditional stories about gods as inventors of various tekhnai and benefactors of human race) flared up with renewed vigor in fifth century Athens especially after the psephisma of Diopeithes and religious trials of intellectuals triggered by the plague and calamities of the Peloponnesian war (Rubel 2014: 39-41 plausibly argues for 430 B.C., traditional date 432). In modern Europe after the age of Enlightenment this "ancient quarrel" took again acute form in the $19^{\text {th }}$ century (this time without $\mu \omega \dot{\lambda} \omega \pi \varepsilon \varsigma$ 'bleeding scars' and death penalties for opponents) due to the explosion of evolutionary theories in biology, cosmology and social sciences. Hence the striking typological similarity (and in some cases, genetic connection) between the anthropology of Sophists and Democritus, on the one hand, and the anthropology of Taylor, or approach to mythology in nature-myth school, on the other. The adherents and the proponents of the new Ionian picture of the world in Athens in the era of Pericles (and later, in the era of the Peloponnesian war)

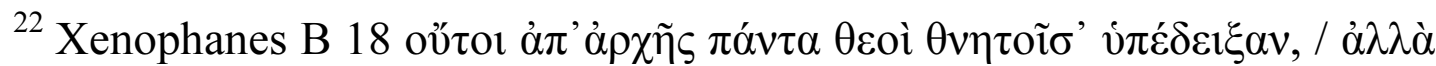

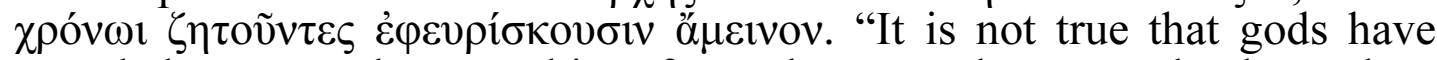
revealed to mortals everything from the start, but mortals themselves search and find gradually what is better".
} 
were Anaxagoras, Archelaus, Protagoras, Prodicus and the Author of the Derveni Papyrus (Prodicus' Horai), and for some time (3020th or 20th years) Democritus, whose ideas could then become known to the Athenian public. All these thinkers were like-minded, the author of Dissoi Logoi combines them all under the general heading of Anaxagoreioi and contrasts them with the opponent group of Pythagoreioi which no doubt included the Eleatics. The Pythagoreioi, like the creationists of the 19th century, denied evolution and counterposed to it the doctrine of the divine demiourgos; to the Ionian and sophistic Kulturgeschichte and the new anthropology they counterposed the theory of divine benefactions and revelations to human race. Xenophon (Memorabilia IV, 3, cf. Lebedev 2019: 579 ff.) ascribes such anti-evolutionist and creationist view of the origin of civilization to Socrates. Plato who always sided with Pythagoreioi, replied to Democritus and Protagoras by reviving the ancient Pythagorean doctrine of creation by divine mind in his Timaeus: the philosophical Gigantomachia or battle over being described in Plato's Sophist continued in the 4th century B. C. and for centuries after until the final victory in late antiquity of the Platonic tradition and the total eclipse of naturalism (together with genuine physical science) for the next 1000 years or so $^{23}$.

Reinhardt (1912: 512), attributed the fragment 580L. / D30 to

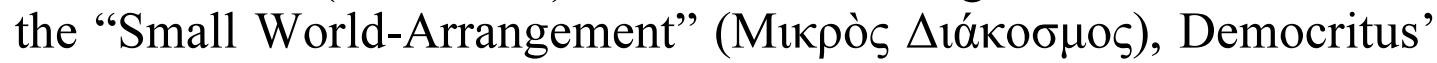
history of civilization, which stands in the same relation to the

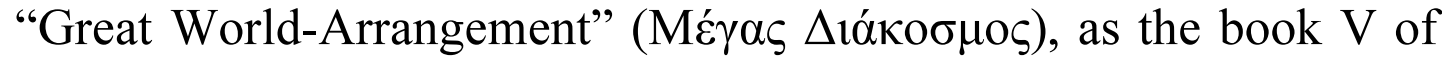
Lucretius' De rerum natura to the books I-II. This thesis of Reinhardt is hard to resist, but while accepting it, we will not agree with the attribution of the "Great World-Arrangement" to Leucippus. We agree with Luria, that a "separate tradition" on 'Leucippus' did not exist and that all texts quoted under this name should be ascribed to Democritus. Luria leaves the question of the historical existence of Leucippus open, we follow Epicurus and Hermarchus, who denied the historical existence of Leucippus (D.L.

${ }^{23}$ On the ancient Pythagorean roots of the theological concept of god as 'mind' (voũs) see our works on Epicharmus, Lebedev (2017, ) and on Parmenides (Lebedev 20172). On divine demiourgos in Philolaus and other Pre-Platonic thinkers see our article on idealism Lebedev, 20192. The later story of philosophical Gigantomachia is masterfully told in the works of Lloyd Gerson. See especially his "Platonism and naturalism" (2020). 
$10.13)^{24}$. According to our hypothesis, "Leucippus" is a fictitious name of an "ancient sage" (a fashionable literary device in the Sophistic age), used as a pseudonym by Democritus, under which his Megas Diakosmos circulated in Athens at the time of his visit and later. The end of the $30 \mathrm{~s}-$ the beginning of the 20s in Athens after the psephisma of the diviner Diopeithes (432 B.C.), that outlawed the teaching of the new Ionian astronomy as asebeia (denial of patrioi logoi about the divinity of heaven), was a time of a "witch hunt", that is, of prosecution of Anaxagoreioi, the first victim of which was Anaxagoras himself. Even the addition of the quasidivine Mind to the Ionian Vortex in his version of cosmogony did not save Anaxagoras from torture and conviction ${ }^{25}$. Democritus did not have the protection of Pericles, like Anaxagoras, and in his version of the Vortex cosmogony there was no quasi-divine Nous (reminiscent of Zeus as he "knows everything", $\pi \alpha$ óv $\tau$ है $\gamma v \omega)$ that could be cited to judges as a proof that he was not an atheos. He was

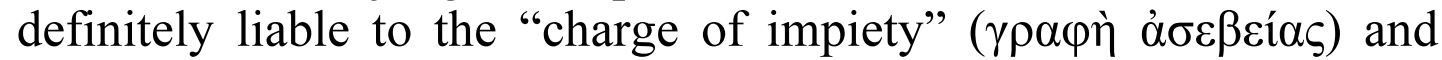
faced torture (as alien resident) and death penalty. Therefore, Democritus prudently protected himself from prosecution with a pseudonym. Aristotle and Theophrastus had in their hands an Athenian copy of Democritus Megas Diakosmos published under the name of "Leucippus". But Thrasyllus in his catalogue of the works of Democritus did not doubt the authorship of Democritus, noting that the view of Theophrastus is exceptional (D.L. 9.46). Outside of Athens and in later times Megas Diakosmos must have circulated under the real name of Democritus. Epicurus probably brought his copies of Democritus' works to Athens from Asia Minor, that is why both he and Hermarchus were so sure that "philosopher Leucippus never existed". In his Mikros Diakosmos Democritus expounded his history of civilization, including his theory of the origin of language and religion. The original religion of mankind in this work was presented as a worship of the elements and luminaries with no temples or altars. It is in this context that Democritus cited in support of his theory the anthropological

${ }^{24}$ For some additional arguments in support of Epicurus' evidence see Lebedev 1984: 13-15. Gemelli (2013) rightly eliminates a separate chapter for 'Leucippus'.

${ }^{25}$ According to the new reading by Acosta Mendez of a passage in Philodemus" Rhetoric 4, PHerc. 245, fr. 7 Anaxagoras "after being whipped showed to the judges bleeding scars', $\mu \alpha \sigma \tau \imath \gamma \omega \theta \varepsilon i \zeta ~ \mu \omega ́ \lambda \omega \pi \alpha \varsigma$

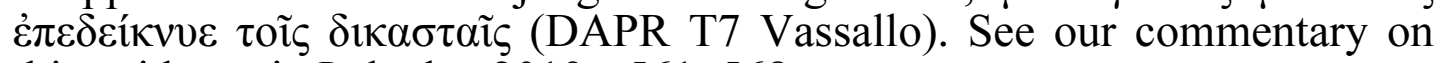
this evidence in Lebedev 2019, $561-568$. 
evidence from the religious practices of barbarians, following the rule "it was in ancient times among the Greeks as it is now among the barbarians". The case of Zoroastrian magoi provided a perfect

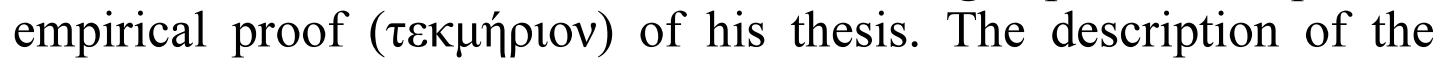
ritual 'under the rays of the sun' with no temple or altar, was followed by an accurate quotation from the Yasht 1 of the Iranian Avesta based on Democritus' own translation from Avestan. The "names" of Ahura Mazda (especially $\beta \alpha \sigma i \lambda \varepsilon v ́ \varsigma$ and $\pi \alpha ́ v \tau \alpha$ oĩ $\delta \varepsilon v$ ) had unmistakable similarity with the Greek image of Zeus. But these names were applied not to an anthropomorphic divine being. The hands of the magoi 'imploring' the Persian 'Zeus' were stretched not towards a statue, but towards "that place which we, the Greeks, at present call air". So, the word zeus in ancient times meant air, but now ( $v \tilde{v} v$ ) it has been reattached to a formidable anthropomorphic

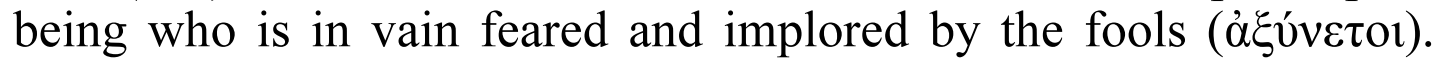
Democritus speaks with respect about Iranian magi, but one can discern a smile of the "laughing philosopher" over his credulous compatriots.

\section{Commentary to Democritus fr. 580 Luria/B30 DK}

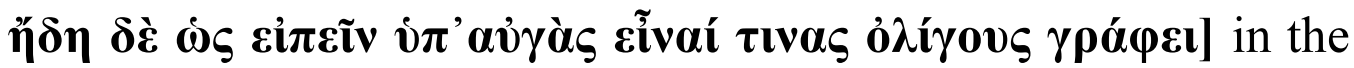
Stromata version (S) the text of the Protrepticus version (P) is preceded by the words i $\pi$ ' $\alpha$ vó $\alpha$ 'under the rays of the sun'. The two quotation have the same reliability status: Clement is one the best sources of verbatim quotations from early Greek philosophers. Therefore, the versions (P) and (S) should be taken as complementary. The words $\omega \varsigma$ sineĩv in (S) apparently belong to Clement together with the combination $\eta \dot{\delta} \eta \delta \dot{\varepsilon}$. The latter occurs in 62 instances in Clement teste TLG, it often introduces an additional point or an example in a series with emphatic meaning ${ }^{26}$. This fact makes not only redundant, but impossible Münzel's correction of

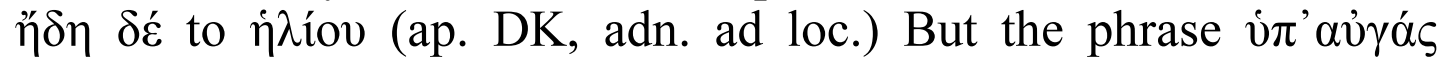
'under the rays of the sun' occurs in the complete works of Clement elsewhere only two times, one of which is Homeric verse (Strom. 7.4.25.3; Paedag.3.11.63.3). This means that the phrase $\dot{0} \pi^{\prime} \alpha \hat{v} \gamma \alpha \dot{s} \varsigma$ is not a part of Clement's regular lexicon, and therefore the chances

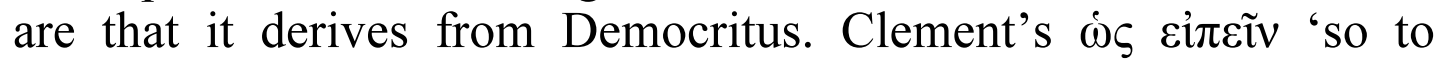
speak', according to one possibility, marks a poetic phrase. The vocabulary of the Early Ionian prose and of the Homeric tradition

${ }^{26}$ On the emphatic ("reinforcing") meaning of $\eta \hat{} \delta \eta \delta \grave{\varepsilon} \kappa \alpha i$ in Aristotle's Politics see the painstaking analysis of Aristid Dovatour (1965: 65 ff.) 
have many shared words alien to Attic and koine. Even if considered as a paraphrase by Clement rather than a verbatim quotation (which is less likely), it still contains a unique and valuable information on Democritus' context: the logioi men perform their ritual and invoke Zeus 'under the rains of the sun', i. e. in the open air, and not in a temple or sacred temenos. This use of the phrase (not in LSJ) in the sense of 'being uncovered', 'in the open air' should be distinguished from the familiar poetic formula for 'being alive', 'until I see the rays of the sun' etc. (LSJ. s.v.1) that does not fit the context in Democritus ${ }^{27}$.

The reason Diels did not even consider the possibility of attributing the words $v \pi$ ' a jox́s to the quotation from Democritus is understandable: Diels regarded the fragment as a polemic of Democritus with Diogenes from Apollonia (which was a mistake), and since Democritus could not say that Diogenes exposed his thesis of the identity of Zeus and air 'under the rays of the sun' Diels disregarded these words as Clement's own worthless addition. This mistake turned into a dogma persisting for more than a century, although the two assumptions of Diels (the polemic with Diogenes and the "ironical" meaning of $\lambda$ ó $\gamma 10$ ) underlying this error have long been criticized and rejected.

Although the words i $\pi$ ' $\alpha$ vó $\alpha_{\varsigma}$ are read only in (S), in the context of the quote $(\mathrm{P})$ there are indications that they may have been lost in MSS transmission. Right before the quote in the preceding context (P), Clement combines the standard Platonic metaphor of mind as the inner "eye of the soul" and the Christian metaphor of the LogosChrist as "the inner sun of the soul." If we restore in (P) the words vं $\pi$ 'av่yós in the same position as in (S), the transition from Clement's context to Democritus's quotation becomes more logical

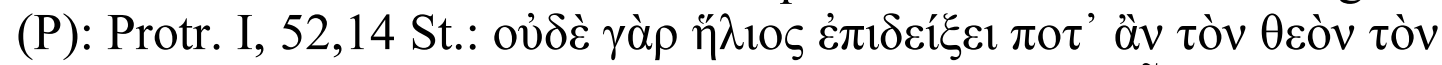

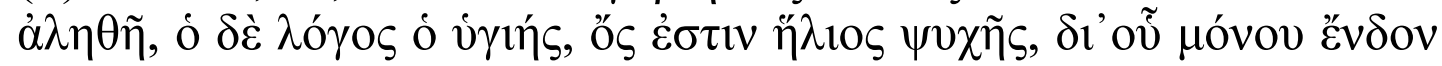

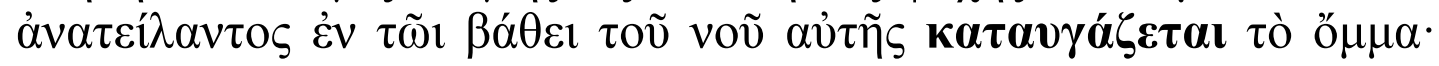

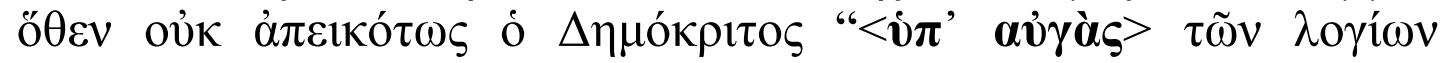
$\dot{\alpha} v \theta \rho \omega ́ \pi \omega v$ ò $\lambda$ ífovৎ ..." $\kappa \tau \lambda$. "And the (visible) sun will never show

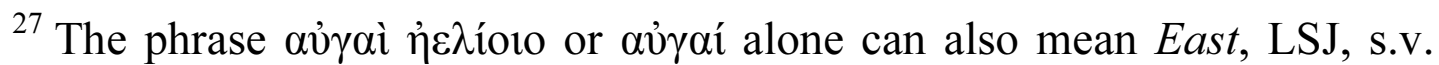

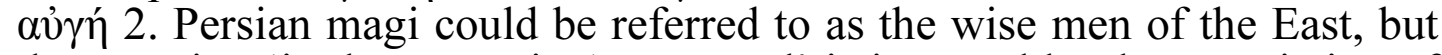
the meaning 'in the open air, 'uncovered' is imposed by the association of magi with worship 'in the open air'. In the only another instance of the phrase in Clement (Paedag. 3.11.63.3) that condemns cosmetic coloring of hair, he prohibits 'covering' old man's grey hair and admonishes to expose

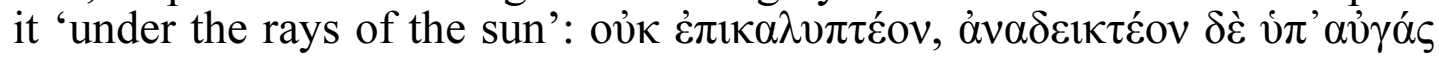
$\kappa \tau \lambda$.
} 
the true god, but only the sound Logos, which is the sun of the soul; only when this (= internal) sun rises in the depth of the mind, the eye of the soul is illuminated-by-rays, so Democritus aptly said that "under the rays of the sun there are few learned men..." etc. Clement turns the anthropological fragment of Democritus into a

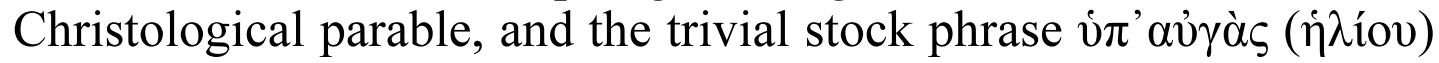
"under the rays of the sun" (= in the open air) becomes a symbol of mystical illumination revealing to the 'few' pagan sages the true God of Christian monotheism. It is conceivable that by saying $\omega s$

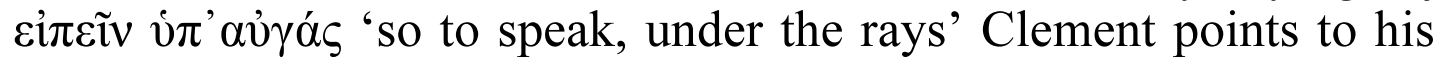
own metaphorical reinterpretation of the phrase 'under the rays', which in the text of Democritus is employed in the ordinary sense, but the glorification of the one and only god, the giver of all goods, in the prayer of "learned men" (in their logos) is still compared with the mystical illumination of the soul by the Christian ('sound') Logos.

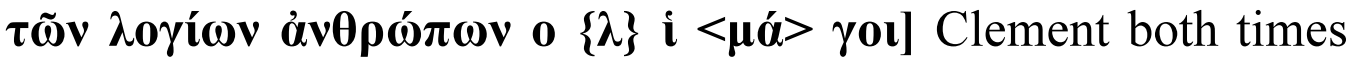
quotes Democritus fr. 580L./B30 in similar contexts: a selection of quotations from Hellenic philosophers and poets who in their search for a true god foreshadowed the one and only creator God and of Logos the Saviour. Both times he quotes Democritus with

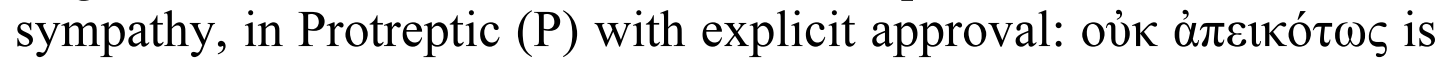
a litotes employed for praise. The word óníror is read in both versions, the word $\lambda$ ó $\gamma 10$ only in $(\mathrm{P})$. This means that Clement used

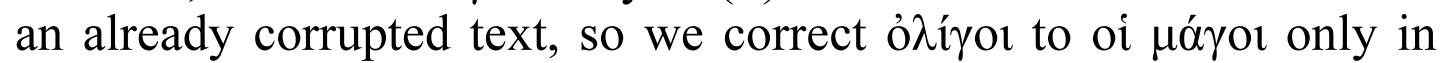
our reconstruction of the original text of Democritus, but not in the text of Clement. By ó $\lambda$ íyor Clement apparently understood "those few" of the pagans who, in their search for the true god foreshadowed the Christian faith, just as Justin Martyr considered Heraclitus and Socrates to be "Christians before Christ". Our

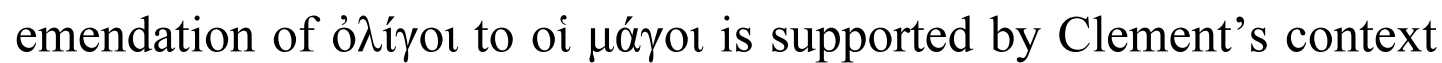
in version (S). In both collections of monotheistic quotes from pagan poets and philosophers, Clement quite probably relied on some pre-existing Hellenic collections of quotes (e.g., Stoic or Platonic) whose purpose was different, i.e. demonstrating that Platonic or Stoic doctrine is supported by a consensus of famous names. Immediately after the quote from Democritus fr. 580L./ B30, Clement refers to the demiourgos in Plato's Timaeus and to the eschatology of Politeia book X. He identifies the Platonic Er, the son of Armenius, who rose from the dead, with Zoroaster and 'confirms' this with a quote from the Pseudo-Zoroaster. (Strom. I, $395,17-24)$. Thus, in the source of Clement, both the (imaginary) 
theology of Democritus in fr. 580L. and the eschatology of Plato's Republic may have been presented as doctrines of Magoi and Zoroaster, who according to Xanthus of Lydia lived 6000+ years before Xerxes. In post-Hellenistic religious philosophy, the authority of a doctrine depended on its antiquity. It should be emphasized that our interpretation of the Democritus fragment about logioi does not depend on the emendation of the word ó $\lambda$ íror into oi $\mu$ ó $\gamma o 1$; on the contrary, our emendation follows from our reinterpretation of the whole fragment. This reinterpretation, however, is not conjectural, but is based on evidence: it relies on the commonly neglected part of Democritus' text (í $\pi^{\prime} \alpha \dot{\gamma} \gamma \alpha \varsigma_{s}$ ), on the use of the phrase $\lambda$ ó $\gamma 101$ $\alpha \nu v \theta \rho \omega \pi \mathrm{or}$ in Democritus, on the verbal coincidences between the text of the fragment and Yasht 1 of Avesta and other considerations in the above analysis.

We cannot exclude the possibility of an alternative explanation: the words $\mathrm{O} \Lambda \mathrm{I} \Gamma \Omega \mathrm{N}$ and $\Lambda \mathrm{O} \Gamma \mathrm{I} \Omega \mathrm{N}$ are anagrams, therefore the word meaning "learned" could be misread as "few", and then, as a result of contamination, the correct and incorrect reading were combined in a strange phrase $\tau \tilde{\omega} v \boldsymbol{\lambda} \mathbf{o} \gamma \mathbf{i} \omega \mathbf{v} \dot{\alpha} v \theta \rho \omega ́ \pi \omega v$ ò $\lambda \mathbf{i}$ yol 'few of learned men'. Still, the reading oi $\mu$ ó $\gamma o$ remains preferable and is supported by the 'Zoroastrian' context of Clement's source in (S).

$\Lambda$ ó $\gamma 101 \not \alpha v \theta \rho \omega \pi \mathrm{o}$ is a set phrase abundantly illustrated by literary and philosophical texts, including a verbatim quotation from

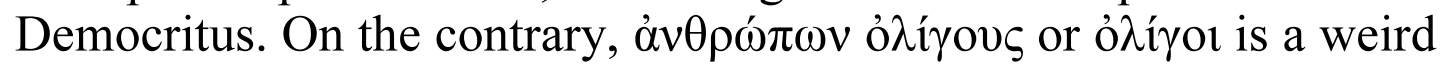

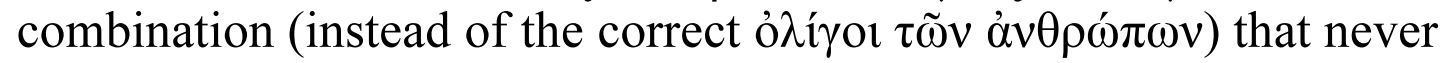
occurs elsewhere in the complete TLG corpus of Greek texts. Even the more normal variant ó $\lambda \hat{i} \gamma o r \quad \tau \tilde{\omega} v \dot{\alpha} v \theta \rho \omega \dot{\pi} \pi \omega v$ gives only two instances from the authors of the pre-Byzantine time in a complete corpus search in TLG. The reason for this is obvious: standard Greek usage requires ỏ $\lambda$ ífor ớv $\theta \rho \omega \pi$ or (innumerable instances!), not

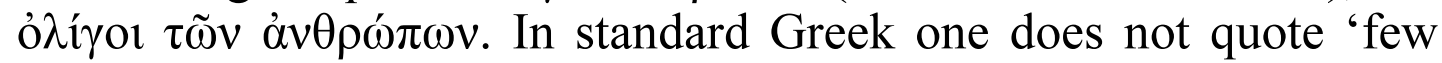

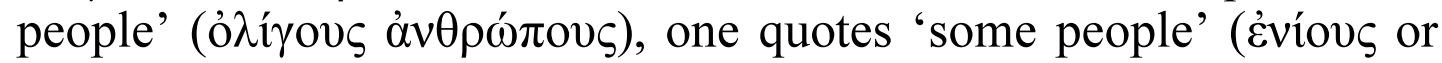

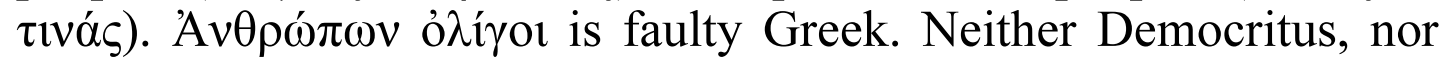

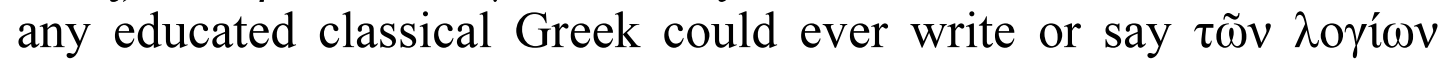

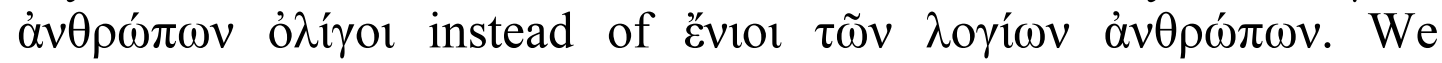
conclude that the word ó $\lambda$ íyor is undoubtedly a corruption, most probably of oi $\mu$ ó $\gamma o 1$, less probably of $\lambda$ ó $\gamma 101$.

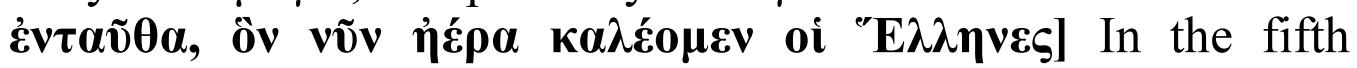
century, the identification of the Zeus of the popular religion with air was widespread, mainly among Ionian physiologoi and Ionian sophists: Epicharmus B 53, Diogenes of Apollonia A 8, Derveni Papyrus, col. XIX, 2-4 et passim. In Heraclitus and Empedocles, 
Zeus is identified not with sublunary air, but with celestial fire or aither, whereas air is correlated with Aides. According to the Derveni author (Prodicus' Horai), the name of Zeus originally meant 'air' or 'vortex', but subsequently, as a result of a language error or misunderstanding by hoi polloi, it was attached to anthropomorphic god portrayed by poets and sculptors. In this connection, Prodicus referred to Persian magoi (PDerv. Col.VI), and like Democritus regarded their 'open air' worship as a barbarian survival, providing anthropological evidence in support of his theory of original 'natural religion'. We have argued elsewhere that Prodicus may have been familiar with the atomic theory of Democritus and the doctrine of eidola. The ancient religion of Persian magi, according to Democritus, preserves the original meaning of the word ZEY $\Sigma$ among the Greeks: in ancient times it meant 'air' or atmosphere. 'Now we Greeks call' air by another

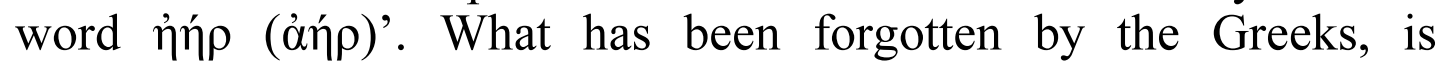
remembered by magi, the guardians of ancient knowledge among the Persians. Imploring the Persian 'Zeus' Ahura Mazda, the magoi do not stretch their hands towards an anthropomorphic statue in a temple, but raise in the air. Apart from the lack of temples and altars in Persian religion, the Greeks were particularly amazed by the absence of statues and the ban on depicting God in a human shape. Russell (2001) and Ahmadi (2014) have persuasively demonstrated that the magoi, mentioned in column VI of the Derveni Papyrus, are not Greek charlatans, but genuine Iranian magoi performing a Zoroastrian ritual. We do not hear in the sources about Prodicus' travels in eastern countries. His lectures were in high demand in various Greek cities, he had no time for such unrewarded trips or for learning Persian language like Democritus. Therefore, he most probably derived his information on Persian magi from literary works of Greeks who either resided or traveled in Persia or Achaemenid Asia Minor. Heraclitus, Xanthus of Lydia and, last but not least, Democritus come into consideration.

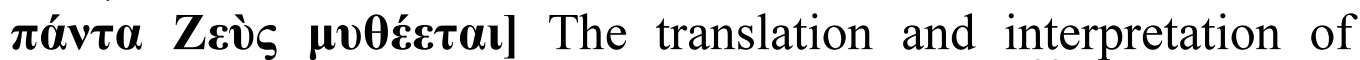
$\mu \nu \theta \varepsilon \dot{\varepsilon} \tau \alpha l$ have caused headaches for commentators ${ }^{28}$. Diels-Kranz

${ }^{28}$ Gemelli Marciano 2013: 368-369 offers an unfortunate solution of the problem by cutting the quotation from Democritus after $\mu v \theta \varepsilon \tilde{\tau} \sigma \theta \alpha$. Even if one retains the oratio obliqua $\Delta i \dot{\alpha} \mu \nu \theta \varepsilon i \tilde{\sigma} \theta \alpha$, these words cannot be translated as "Das All mit dem Wort 'Zeus' bezeichnen". The word Zeús

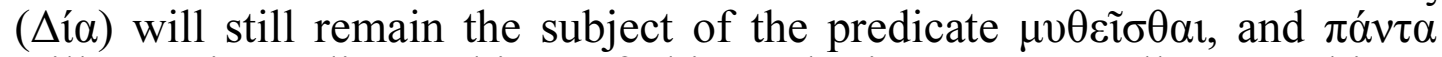
will remain a direct object of this verb, i. e. 'Zeus tells everything'. Wilamowitz was trying to achieve something similar by torturing in vain 
hesitatingly translate "Zeus beredet mit sich selbst (?)" (DK, II, 151), citing Hom. Il. 17. 200. But the verb $\mu v \theta \varepsilon$ co $\alpha_{\alpha}$ does not have

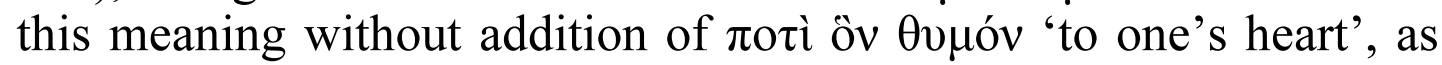
has been rightly observed by Luria. Ahura Mazda does not "discuss with himself" anything, he utters the prophetic word of truth. Refuting this mistranslation, Luria moves in the right direction, pointing to the magical character of Zeus's "words": he compares it with the biblical cosmogonic word of God ("And God said") and Homer's verse about the soothsayer Halitherses, who knows how to

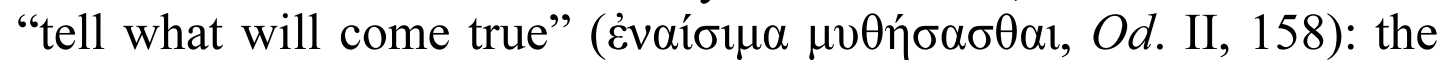
words of the oracle become deeds (Luria, p. 557 and note 26). Words that come true are words of truth. In Zoroastrianism, the embodiment of truth is the wise Lord Ahura Mazda, and the embodiment of lies is his adversary Ahriman. Democritus' phrase $\pi \alpha ́ v \tau \alpha \mu v \theta \varepsilon \dot{\varepsilon} \varepsilon \alpha 1$ 'says all-that-comes true', adequately conveys the meaning of the fourth name of Ahura Mazda 'aša vahišta' 'O Best Truth' in Yt. I, 7, 5.

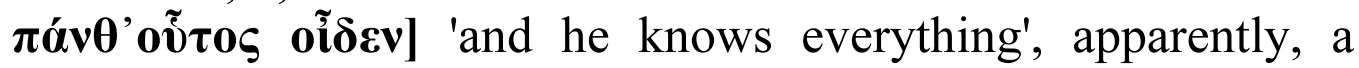
general summary of the meanings of the names 6-7: Intelligence'(xratuš) - 'Intelligent' (xratuma) and names 8-9 'Insight' (cistiš) - 'Insightful' (cistiuuma). Compare also with the seventeenth name 'All Seeing' (vispa hišas).

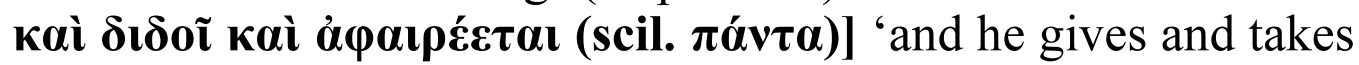
everything' corresponds to the names 10 and 11 'Beneficence' (spano) and 'Beneficent' (spananuha) in the text of Avesta. Compare also '(O you who are) Every Good Thing Created' (vispa vohu) in the fifth name.

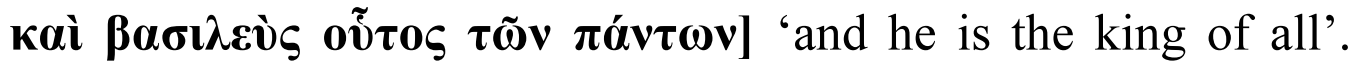
Exactly matches the names 12 and 13 'Lord' (ahuro) and 'Most Powerful' (seuuišto).

\section{Bibliography}

Ahmadi, A. 2014: The Magoi and Daimones in column VI of the Derveni papyrus. Numen (2014), 484-508.

Cole, Th. 1967: Democritus and the Sources of Greek Anthropology. Toronto.

De Jong, A. 1997: Traditions of the Magi. Zoroastrianism in Greek and Roman literature. Leiden; New York.

the text of Protrepticus. The supposed meaning 'to name, to designate' of the verb $\mu v \theta \dot{\delta}$ o $\alpha$ is is unattested and unlikely. Therefore, the comparison with Orphic theogony (ibidem, p. 519) fails. 
Diels, VS ${ }^{4}$ — Diels, H. (Hrsg.). 1922: Die Fragmente der Vorsokratiker. 4. Aufl. Berlin.

DK - Diels, H., Kranz, W. (edd.). 1951: Die Fragmente der Vorsokartiker. 6-te Auflage, Berlin.

Dovatour, A. 1958: The scientific and narrative style in Herodotus. Leningrad (in Russian).

Доватур, А. И. 1958: Научный и повествовательный стиль Геродота. Л.

Dovatour, A. 1965: The Politics and Polities of Aristotle. Moscow; Leningrad, 1965. (in Russian).

Доватур, А. И. 1965: Политика и Политии Аристотеля. М.; Л.

Ferrari, F. 2011: Rites without frontiers: magi and mystai in the Derveni papyrus. $Z P E 179,71-83$.

Franek, Ju. 2013: Presocratic philosophy and the origins of religion. Graeco-Latina Brunensia 18 (1), 57-74.

Geldner, K. 1896: Avesta. The Sacred Books of the Parsis. Stuttgart.

Gemelli, M., Laura, M. (Hrsg.). 2013: Die Vorsokratiker. Bd. 3. Berlin.

Gerson, L. 2020: Platonism and naturalism. The possibility of philosophy. Ithaca; London.

Henrichs, A. 1975: Two Doxographical Notes: Democritus and Prodicus on Religion. Harvard Studies in Classical Philology 79, 93-123.

Horky, Ph. 2009: Persian cosmos and Greek philosophy: Plato's associates and Zoroastrian magoi. Oxford Studies in Ancient philosophy XXXVII, 47-103.

Kingsley, P. 1995: Meetings with Magi: Iranian Themes among the Greeks, from Xanthus of Lydia to Plato's Academy. JRAS, Series 3.5.2, 173-209.

Lebedev, A. 1984: «ФY $\Sigma \mathrm{I} \Sigma$ TA $\Lambda$ ANTEYOY $\Sigma A »:$ Neglected Fragments of Democritus and Metrodorus of Chios. In: Linos Benakis (ed.). Proceedings of the First International Congress on Democritus. Vol. II, Xanthi, Greece, 13-25.

Lebedev, A. 2016: The Origin and Transmission of the Doxographical Tradition Placita Philosophorum (Arius Didymus, Ps.Plutarch, Stobaeus, Theodoret, Nemesius, Porphyrius). In: N. Kazansky (ed.). Indo-European Linguistics and Classical Philology 20 (2), Proceedings of the International Conference, St. Petersburg, 20-22 June, 2016. St. Petersburg: Nauka, 573-633.

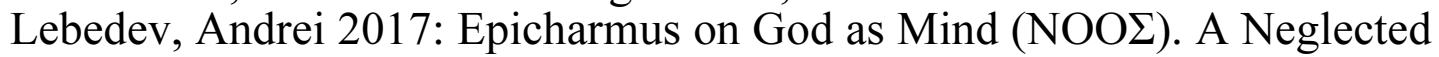
Fragment in Stobaeus. (With some remarks on early Pythagorean metaphysics and theology). In: Artisteas. Vol. XVI (2017) 13-27.

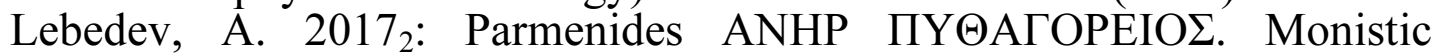
Idealism (Mentalism) in Archaic Greek Metaphysics. In: N. Kazansky (ed.). Indo-European Linguistics and Classical Philology, Proceedings of the $21^{\text {st }}$ Conference in Memory of Professor Joseph Tronsky, St. Petersburg, 493-536.

Lebedev, Andrei 20173: Alcmaeon of Croton on Human Knowledge, the Seasons of Life and Isonomia. Two Additional Fragments from Turba Philosophorum and Aristotle. In: Chr. Vassallo (ed.), Physiologia. Topics in Presocratic Philosophy and its Reception in Antiquity. Trier, 227-257. 
Lebedev, A. 2019: The Authorship of the Derveni Papyrus, A Sophistic Treatise on the Origin of Religion and Language: A Case for Prodicus of Ceos. In: Presocratics and Papyrological Tradition. A Philosophical Reappraisal of the Sources. Proceedings of the International Workshop held at the University of Trier (22-24 September 2016). Edited by Christian Vassallo, Berlin; Boston: De Gruyter, 491-606.

Lebedev, A. 20192: Idealism (mentalism) in early Greek metaphysics and philosophical theology. In: N. Kazansky (ed.). Indo-European Linguistics and Classical Philology. Proceedings of the $21^{\text {st }}$ Conference in Memory of Professor Joseph Tronsky, SanktPeterburg, 24-26 June, 2019, 651-704.

Luria, S. 1970: Democritea. Leningrad.

Luria, S. (ed.). 2007: Democrito. Raccolta de frammenti. Introduzione Giovanni Reale. Milano.

Mayhew, R. 2011: Prodicus the Sophist: Text, Translations, and Commentary. Oxford.

Panaiono, A. 2002: The lists of names of Ahura Mazda (Yašt I) and Vayu (Yašt XV). Roma.

Reinhardt, K. 1912: Hekataios von Abdera und Demokrit. Hermes 47, 492513.

Roubekas, N. P. 2017: An ancient theory of religion. Euhemerism from Antiquity to the present. New York; London.

Rubel, A. 2014: Fear and Loathing in Ancient Athens: Religion and Politics During the Peloponnesian War. London; New York.

Russell, J. 2001: The Magi in the Derveni Papyrus. Nâme-ye Irân-e Bâstân 1.1, Tehran, 49-59.

Taylor, C. C. W. (ed.) 1999: The Atomists Leucippus and Democritus. Fragments. Toronto.

Tuplin, Ch. 2007: Persian responses. Political and cultural interactions with(in) Achaemenid empire. Swansea.

Vasunia, Ph. 2007: The philosopher's Zarathushtra. In: Tuplin (ed.) 2007, 237-266.

Winiarczyk, M. 2016: Diagoras of Melos. A contribution to the history of Ancient atheism. Berlin. 